\title{
Instructional Effectiveness in History Classrooms: An Analysis of Students' Perceptions of Instructional Practices of University Teachers
}

\author{
Saba Zaka ${ }^{1}$, Yaar Muhammad ${ }^{2}$
}

\begin{abstract}
This qualitative case study was conducted to explore the perceptions of History research students about the effectiveness of instructional practices of university teachers. This study assumes that research students are active stakeholders and keen observers, so they perceive their teachers' professionalism very deeply. All students who had completed their coursework and were working on their research work at the MPhil level in the Department of History at a public university were selected to conduct this study. An interview guide was constructed to collect the data, which included three significant dimensions: students' engagement, instructional strategies, and classroom management. Semi-structured interviews were conducted with 7 students who volunteered to participate in the study. Interview data were analyzed using qualitative content analysis. The findings of the study suggest that most students perceived that teachers used a variety of techniques to motivate the students who showed low interest in the class. Moreover, they perceived that the instructional strategies of teachers were diverse, catering to various learning styles of students. However, students also perceived that some teachers had discouraging behaviour on students' questioning and also waste class time gossiping with students due to lack of proper planning. It seems there is a need to develop mechanisms for the professional development of faculty members. In addition, there is a need to find ways to motivate teachers to bring effectiveness to their instruction in higher education classrooms.
\end{abstract}

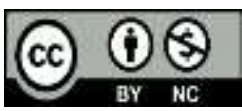

Keywords: Students' Engagement, Instructional Strategies, Classroom Management, Instructional Practices, History Education, Students' Perceptions

1 District Trainer, Literacy and Non-Formal Basic Education Department, Gujranwala. Email: saba.zaka143@gmail.com

2 Assistant Professor, Department of Education, University of Management and Technology, Lahore. Email: yaar.muhammad@umt.edu.pk 


\section{Introduction}

In higher education institutions of Pakistan, the teaching of History discipline is usually aimed at equipping students with effective research skills relevant to academic disciplines, inculcating historical consciousness among them about the human past, and helping students to appreciate the contributions of marginalized groups and subaltern classes (Barton \& Levstik, 2013; HEC, 2017). In addition, this discipline is entrusted with familiarizing the students with political, cultural, religious, and social issues and events in the development of world history and apprising the students with the development of human society with multiple perspectives (Barton \& Levstik, 2013; HEC, 2017). Focusing on Pakistan, these disciplines are also assigned the role of making the students aware of the cultural heritage in South Asia, furnishing students with the knowledge of political, constitutional, and historical development in Pakistan, and using historical knowledge to resolve the problems of Pakistan (HEC, 2017).

An MPhil degree is a preparation for entry-level research in History, and coursework forms an important component in which students are provided advanced content knowledge of theories, and students are trained to use advanced research methods specific to the history discipline (HEC, 2016). Teacher's effectiveness concerning the preparation of students for challenges of research in this degree is essential, especially when "the professional training for getting the job as university teachers is not a prerequisite" (Saleem, Masrur \& Afzal, 2014, p. 164). However, in the Pakistani context, there seems a dearth of empirical research that explicitly measures or describes engaging instructional practices of teachers at the university level. Most of the studies exploring or measuring teacher instructional effectiveness in using effective instructional practices or its related constructs and concepts are conducted in the school context (e.g., Ahmad et al., 2012; Nadeem et al., 2011; Rehmani, 2006; Saeed \& Mahmood, 2002).

In addition, previous research in History education in the Pakistani context has been mainly focused on analysing textbooks' biasness in a number of ways. The research on History curriculum has largely explored national identity; and the representation of different identities and their relations with national identity in textbooks and curricula (Ahmad, 2004; Aziz, 1998; Dean, 2005; Lall, 2008; Nayyar \& Salim, 2003; Rosser, 2003a, 2003b; Saigol, 1995; Zaidi, 2011). The reviewed literature has also suggested that university teachers' classroom practices as yet largely 
neglected area in the Pakistani context. This study is designed to fill this gap.

The study of instructional effectiveness in higher education classrooms is a necessity in developing countries like Pakistan because higher education teachers play a key role in the education system and are responsible for developing a research culture in the classroom. In addition, teachers are also responsible for shaping the lives of the students so that they can become effective citizens of the society. At the MPhil level, students are active stakeholders and keen observer. Therefore, it is assumed that they understand their teachers' professionalism very deeply. In light of the significance of teachers' effectiveness, the researchers planned this study to understand university teachers' instructional effectiveness through students' perceptions.

In this study, three specific questions were addressed:

1) What are the perceptions of students about the effectiveness of students' engagement related practices of university teachers?

2) What are the perceptions of students about the effectiveness of instructional strategies related practices of university teachers?

3) What are the perceptions of students about the effectiveness of classroom management related practices of university teachers?

\section{Literature Review}

In fact, there are many dimensions of the effectiveness of university teaching that can be used to judge teacher effectiveness since "the constituent elements of teacher effectiveness are still a topic of debate" (Graham, 2007, p. 1). However, this study was focused on teaching effectiveness in the following three significant dimensions, that is, student engagement, instructional strategies, and classroom management. The focus on three selected dimensions was decided by a preliminary analysis of a focus group discussion with history students, which underscored the students' relative greater importance to these dimensions. Hence, they were chosen for further exploration.

Students' engagement is very significant in the academic achievement of the students. Engaged students actively participate in classroom discussions, show their interest and passion for learning, and exert their maximum efforts in performing classroom activities (Fredricks, Blumenfeld, \& Paris, 2004). On the other hand, disengaged students exhibit disruptive behaviours in the classroom and have low grades during the assessment (Reyes, Brackett, Rivers, White, \& Salovey, 2012). The dropout rate of such students also increased, and there is less possibility of 
achieving educational goals (Kaplan, Peck, \& Kaplan, 1997). According to Skinner and Belmont (1993), if students are not fully engaged, then they become more passive learners, feel bored, and also show angriness for staying in the classroom. However, students who are highly engaged and regularly attend the classroom secure high grades than the students with lower levels of engagement (Klem \& Connell, 2004).

Student engagement and academic achievement are considered as outcomes of teachers' effort to engage students rather than merely as individual student attributes or traits (Urdan \& Schoenfelder, 2006). When a teacher appreciates higher-order thinking, deliberately makes efforts to integrate prior knowledge of students into his instruction, and sets clear norms for classroom manners, it helps him in enhancing students engagement and academic achievement (Emmer \& Stough, 2001; Reyes et al., 2012).

Teacher's ability to cultivate an emotionally supportive classroom environment helps students perform better academically (Reyes et al., 2012). According to Jennings and Greenberg (2009), if teachers create a positive emotional classroom environment for learning, then students feel comfortable in the classroom and become more enthusiastic due to a safe and valuable place of learning. As a result, students are more connected and engaged in the teaching-learning process and become academically more successful. If the teachers are caring, supportive, and emotionally strong, then their students feel a sense of belongingness and are emotionally attached to their teachers and become engaged in the learning process (Battistich, Schaps, \& Wilson, 2004). If students are emotionally attached to teachers, then their engagement in classroom activities automatically promotes (Birch \& Ladd, 1997). On the other hand, if the students are emotionally unresponsive to the learning environments, then they feel disconnected and are less engaged in learning activities (Orlich, Harder, Callahan, Trevisan, \& Brown, 2010). As a result, the academic performance of the students suffers. Thus, effective university teachers must be knowledgeable, skilled, and prepared for creating optimum learning experiences for students.

The ineffective instructional practice is one of the major causes of students' poor academic performance. Charles, Kimutai, and Zachariah (2012) suggest that effective teachers plan their lessons before the lecture. Effective teachers have the quality of intrinsic motivation and automatically manage themselves to follow the implications of the lesson plan, better prepare themselves to synthesize and evaluate the scripted 
plans, and more skilful at using new teaching strategies and methods (Peterson, 2011). Furthermore, effective teachers build strong relations with their pupils, engage the instructions, practice evidence-based classroom management, and instructional strategies, and deliver concrete and implicit information (MacSuga-Gage, Simonsen, \& Briere, 2012). In addition, effective teachers give priority to the teaching material that is most relevant and aligned to the learning objectives of the course and covers the basic material by focusing on core topics and providing sequential information before moving towards new topics (Orlich et al., 2010; Westwood, 2009).

The third dimension that is used in this study to evaluate the teaching effectiveness of university teachers is "classroom management." Evertson and Weinstein (2011) define classroom management as "the actions teachers take to create an environment that supports and facilitates both academic and social-emotional learning" (pp. 4-5). Poorly managed classrooms lead to ineffective teaching and learning (Saleem, Muhammad, \& Masood, 2019, 2020a, 2020b). Effective classroom management is usually dependent on the standard of establishing a conducive environment of the classroom encompassing effective student-teacher relations. Indeed, effective classroom management supports and facilitates effective teaching (Shindler, 2009).

Classroom management has its significance that is admired from a social practice perspective and the perspective of effective teaching. From the social practice perspective discipline, strategies of teachers are suggested as a powerful force for promoting the sense of students' responsibility in the classroom (Lewis, Romi, Katz, \& Qui, 2008). Moreover, Lewis (2001) stated that the social practice perspective helps in producing more responsible and reasonable individuals at a grand vision. Classroom discipline is mandatory in creating a conducive learning environment because the misbehaviour of the students distracts the teaching-learning process and spoil the effectiveness of most planned lessons (Bluestein, 2014; Scrivener, 2012). Behaviour problems faced by the teachers in the classroom create stress and burn out for the teachers; either they are new or experienced (Garrett, 2014).

Effective classroom management is clearly associated with teachers' ability to set a suitable tone to get students' cooperation and their respect in the class (Burden \& Williams, 1997). Teachers' way of maintaining classroom discipline has a great effect on the way teachers present themselves as an effective teacher (Rogers, 2015; Shindler, 2009). 
To deal with discipline problems, most caring teachers select relationshipbased discipline strategies rather than over coercive strategies like aggression and punishing the students (Laslett \& Smith, 2002; Scrivener, 2012). The time utilized by a teacher to deal with the misbehaviour of the students because of his or her poor classroom management skills results in students' poor rate of classroom engagement (Laslett \& Smith, 2002).

\subsection{Research Design}

\section{Research Methodology}

The instrumental qualitative case study research design (Stake, 1995; Yin, 2014) was used to understand the perceptions of students regarding the effectiveness of instructional practices of university teachers. An instrumental case study is a type of case study which is not designed to study a particular case but is designed to provide insight into a particular phenomenon (Stake, 1995, 2013; Yin, 2014). The instrumental case study design was the most suitable to conduct this study because this design helped in examining a complex phenomenon occurring in a particular situation (Lune \& Berg, 2017). In many situations, the case study approach chooses a small physical area and selects limited participants of the study (Andrade, 2009; Yin, 2018). In this case study, the researchers investigated a complex problem of teacher effectiveness through in-depth-interview data obtained from students for a complete and in-depth examination of teacher effectiveness focusing on three dimensions.

\subsection{Population \& Sample}

The purposive sampling technique was used to select participants for this study (Patton, 2015). All MPhil students enrolled in the year 20152017 in a public university in Gujrat (Pakistan) were invited to participate in the study. Moreover, an in-depth understanding of the teacher effectiveness was required; the logic and power of purposeful sampling certainly ensure this (Yin, 2018). As a result, seven students were selected for interviews.

\subsection{Instrumentation}

Semi-structured interviews were conducted to collect information from the participants. A semi-structured interview was used as an instrument for this study because rich information can be collected through the interview (Roulston \& Choi, 2018). The interviewer can explain its questions according to the need, and the interviewee may also provide a bulk of information that is helpful for the study (Brinkmann, 2013; Roulston, 2014). Semi-structured interviews are usually used in case-study research as an instrument (Merriam, 2009). 
Semi-structured interviews were mostly guided by a list of questions, but open-ended and flexible questions were used in the biggest portion of the interviews (Brinkmann, 2013; Seidman, 2006). Students' perceptions regarding student engagement were elicited by asking them to comment on teachers' strategies to enhance students' interest in the teaching-learning process, to deal with these students to engage naughty students in the teaching-learning process, to engage students' in cocurricular activities, and to engage slow learners in classroom activities. Also, they were asked open-ended questions regarding instructional strategies used by teachers in classrooms, teachers' responses to difficult questions raised by the students, teachers' strategies to manage individual differences in the teaching-learning process, teachers' strategies for effective communication with all students in classrooms, teachers' strategies for encouraging the students and teachers' strategies for making the teaching-learning process purposeful. Additionally, students' perceptions regarding classroom management were elicited by asking open-ended questions in relations to teachers' strategies for ensuring the participation of all students in classroom activities, dealing with the disruptive behaviour of the students in classrooms, managing time to perform classroom activities effectively, dealing with mischiefs of naughty students during the lecture, and establishing their routines to run classroom activities smoothly. Relevant follow-up and probing questions were asked to generate rich data.

\section{Data Analysis \& Interpretation}

Interview data were analyzed using qualitative content analysis (Schreier, 2014). Transcription of all the interview transcripts was done verbatim, and later each transcript was read in detail for pre-coding (Saldaña, 2013). These analytical steps helped in identifying significant passages topics for addressing research questions of the study. Starting with the complete coding of one participant's data first, the researchers coded the second participant's data. Similarly, transcripts of all participants were coded. Later on, all similarly coded data were clustered, thus helping in identifying sub-categories from coded data (Miles, Huberman, \& Saldaña, 2020). Numerous categories and sub-categories related to students were finalized for reporting of the results. Significant passages of the interview transcripts were identified as quotes were to provide "evidentiary warrants" (Saldaña, 2011, p. 125) for the reporting of the findings. 
This section deals with the analysis of students' perceptions of instructional effectiveness at a higher level.

\subsection{Students' Engagement}

Students' perceptions of the teachers' effectiveness in relation to motivating the students who show low interest in the class were investigated. Most students stated that their teachers often motivated the students who showed low interest in the class. For example, a student stated:

When I joined this university, I felt difficulty in my studies due to the change in the medium of instruction, and my interest in education also got low. In this situation, my teachers encouraged me by saying, 'you should remove the word impossible from your dictionary, you can do, and you will be able to do.' Now with the blessings of ALLAH, my CGPA is very good, and it is all because of my teachers. (Student IV)

When students were asked what type of techniques teachers employed to enhance students' interest in the teaching-learning process, students stated that teachers used different techniques to motivate those students who show low interest in the class. Moreover, very few teachers tried to investigate the background reasons for students' low interest in the class, dealt with such students with affection and sympathy providing them related material for their help, and motivated such students by giving examples of brilliant students' achievements in life.

Most students maintained that their teachers engaged students in co-curricular activities, and they encouraged and motivated the students to participate in co-curricular activities. For this, teachers also worked towards building students' confidence. For example, a student stated that: "Teachers encourage students to take part in sports by encouraging them: You have the ability; everybody has different skills; nobody is born as skilful, and everyone has the capacity to perform" (Student VI). The findings of the analysis revealed that teachers had different strategies to engage slow learners in classroom activities. The majority of the students stated that teachers motivated and encouraged slow learners by providing them opportunities to participate in classroom discussions and activities. Moreover, some students responded that teachers delivered the lecture in an easy way according to the mental level of all the students and offered the students to ask their difficulties again and again. Furthermore, few students 
replied that teachers used intensive questioning and discussion method to engage slow learners in classroom activities. Sometimes teachers also arranged seats round the table for this purpose in order to increase proximity for enhancing students' engagement.

Furthermore, few students stated that their teachers did nothing to engage lazy students in co-curricular activities. When reasons for such behaviour by the teachers were further probed, the students asserted that engaging students in co-curricular activities were mostly done at school or college level, but at a higher level, students were intrinsically motivated. For example, a student commented: "I think teachers do not engage students in co-curricular activities at a higher level. From my point of view, these things are mostly done at school or college level, but at this level, students are themself motivated (Student III).

\subsection{Instructional Strategies}

This section deals with the analysis of the second dimensions of teachers' effectiveness through students' perception at the higher education level, that is, instructional strategies. Students were asked to share instructional strategies used by their teachers to explore students' perceptions about this dimension. Most students stated that teachers used the lecture and discussion method to deliver content in classrooms. For example, a student stated:

Some teachers prefer the discussion method as an instructional strategy, while others use the lecture method the most to deliver their lesson. Two of our teachers deliver lessons through the lecture method and make a discussion about the content at the end of the lesson. (Student IV)

They further added that teachers sometimes used the questioning technique along with the above-mentioned instructional strategies. For example, a student stated: "After delivering some portion, teachers use the discussion method. Then they raise questions. Students also ask questions at difficult points. Students and teachers learn from each other during classroom discussions and through questioning techniques" (Student VI). However, few students showed concern that some teachers often assigned the topic from the course outlines and asked the students to give a lecture on the assigned topic in the next class.

Most students reported that their teachers responded and encouraged the students to raise the questions. Students were also asked how their teachers respond to difficult questions. The majority of the 
students stated that teachers politely responded to every question, and if teachers had no answer in their mind at that time, then they would politely reply to the students asking that they would answer to this question in the next class after searching the right answer. For example, a student responded:

Teachers are not encyclopedias. Sometimes they don't have the answer to a question on the spot. To deal with such a situation, teachers treat the students politely: teachers apologize and say, I will tell you later after searching the accurate answer to this question. (Student V)

Furthermore, very few students replied that if teachers were not aware of the answer to such questions, then they would open their laptops and search the right answer to difficult questions by using the internet. Through internet technology, teachers respond to the students on difficult questions on the spot. However, few students stated that teachers did not like students' questions; rather, they discouraged such students and behaved strictly. Consequently, students felt stress and avoided raising questions next time. For example, a student stated:

Yes! Teachers always try to respond to their students at difficult questions. Most of our teachers answer difficult questions from the students, but some teachers just focus on their lectures. They don't like questions asked by their students and discourage their students from raising the questions during the lecture. (Student II)

Students believed that their teachers considered individual differences of the students during the teaching-learning process and tried to deliver the lecture in an easy way according to the mental level of the students. However, some students replied that teachers had no such considerations and treated the students equally regardless of their individual differences. If an answer was given by a favourite student, then teachers would appreciate them; otherwise, they condemn. For example, a student stated:

Some teachers consider individual differences in the teaching-learning process, but some teachers have no such considerations. They treat all students in a similar way. Some teachers show favouritism towards students. For example, sometimes teachers ignore the answer given by a 
favourite student, but if the same answer is given by their favourite students, then teachers appreciate by exclaiming, Wow! Well done. (Student I)

Furthermore, few students stated that teachers often motivated them to ask them questions about their difficulties in the teaching-learning process. Additionally, very few students stated that teachers arrange the seats around the table to make the teaching-learning process purposeful. For example, a student stated:

My teachers consider individual differences of the students in the teaching-learning process. They try to deliver a lecture in an easy way. They arrange seats in round table shape. Teachers ask the students one by one, 'have you understood the lesson or not? If anybody has any confusion about the topic, then you can ask without any hesitation.' (Student IV)

Perceptions of the students about the ways of effective communication in the classroom were also examined. The majority perceived that teachers focus on seat arrangements for effective communication with the whole class. Moreover, some students stated that teachers tried to make eye-to-eye contacts with all students of the class. For example, a student stated:

Most of the teachers make seating arrangements in a very appropriate way to make effective communication with the whole class before starting the lecture. Teachers try to make eye-to-eye contact with every student of the class and don't ignore any of the students in the classroom. Teachers do their best to communicate with every student in class during lecture. (Student III)

Few students responded that teachers used the questioning technique to make effective communication with all the students. In addition, very few students responded that teachers created a friendly environment and walked in order to keep students focused. For example, a student stated:

Teachers ensure the active participation of all students taking part in classroom discussions. To make effective communication with the students, teachers call the students 
by name and ask them, 'have you understand the lesson which I taught you.' If a student replies yes, then teachers ask the student to repeat what they have taught. Teachers keep sleepy students awake by using this type of technique. (Student IV)

Students were asked about strategies their teachers used to make them creative. All the students responded that their teachers gave assignments to the students according to their area of interest. For example, a student stated: "Our teachers develop creativity among the students by giving them assignments according to their interests. Due to interesting assignments, students don't feel stress and enjoy their work" (Student II). Moreover, most students reported that their teachers gave presentations to the students and guided them to present in upcoming classes. Furthermore, some students replied that teachers arranged study tours to make their students creative. Additionally, teachers gave article and book-reviews to the students to make them creative and enhance their knowledge and skills. Furthermore, few students stated that teachers encouraged self-writing to make the students creative. For example, a student stated: "Teachers encourage their students to think critically and motivate them for selfwriting" (Student I).

Most students perceived that their teachers offered students to discuss their difficulties. Teachers encouraged students to ask questions about their difficulties and were always ready to individually help the students. Moreover, some students stated that teachers wrote the difficult words and their meanings on the writing board then explained these difficult words in detail for a better understanding of the students. Furthermore, very few students replied that teachers got support from internet technology to deliver their lectures in an easy way by showing maps and different places to the students. In addition, their teachers helped the class to become more active before delivering their lectures and tried to involve the students in classroom discussions. Teachers also provided easy material and notes to the students a day before delivering the lecture so that they could point out their difficulties.

\subsection{Classroom Management}

Students were asked to share their views about the strategies used by the teachers to ensure students' participation in classroom discussions. The majority of the students responded that their teachers motivated and encouraged the students to share the ideas about the topic, and in this way, students got involved in classroom discussions. However, teachers' 
practices were biased. For example, a student stated: "There are some teachers who discuss with only two or three bright students of the class and ignore other class students. But some teachers motivate all the students in the class, asking them to participate in classroom discussions" (Student II).

Moreover, few students stated that teachers asked questions from students to ensure students' participation in classroom discussions. In addition, students took part in classroom discussions due to fear of negative marking. For example, a student stated: "After repeated warnings, some students show a lack of interest in classroom discussions. Teachers warn them by saying that he would mark negatively. In this situation, students participate in classroom discussions due to fear of negative marking" (Student I).

Students were also asked whether their teachers gave attention to disruptive students or ignore them. Moreover, they were asked to comment on their teachers' ways to engage in the teaching-learning process. The majority of the students stated that teachers ignored disruptive students once or twice, depending upon the situation: For instance, if teachers were delivering lectures on some important topics, then teachers treated disruptive students with harsh words. Teachers also dealt with them with strict behaviours when the disruption was bad-mannered, but teachers ignored the disruption created by good students. Moreover, some students stated that some teachers involved themselves in the disruption of the students. However, after some amusement, they shifted towards studies. For example, a student stated:

Definitely, teachers give attention to disruptive students, and teachers should give attention to these students because most of the disruptive students are comparatively intelligent than other students, so they should not be neglected. Teachers have an idea about disruptive students, and they know how to deal with these students (Student $\mathrm{V})$.

Furthermore, very few students stated that teachers use questioning techniques and change the topic to current affairs and politics to engage disruptive students in the teaching-learning process. Interestingly, few students stated that the teacher could not punish the students at this level; therefore, teachers insult the students so that they could leave this behaviour. For example, a student stated: “At this level, teachers can't 
punish the students. Teachers just insult the student and ask them not to disturb the whole class and get out of the class" (Student VI).

Students' perceptions of teachers' time management to perform classroom activities were investigated. The majority of the students perceived that teachers did proper planning to perform classroom activities effectively. Teachers arranged activities like discussions, questioning, and sharing their plans with students by writing it on the writing board, effectively managing their time to perform classroom activities. However, some students stated that teachers could not manage their time; therefore, they could not perform classroom activities effectively. For example, a student stated:

Nobody can manage the time effectively, and nobody mismanages the time a hundred percent. Some teachers enter the classroom with the full planning of their classroom activities. They deliver the lecture. After the lecture, they ask questions from the students and answer difficult questions raised by the students. On the other hand, some teachers come in the classroom with a lack of planning and do not manage their time to perform classroom activities effectively. (Student III)

Few students perceived that most teachers did not plan their activities according to students' knowledge, dispositions, and skills; therefore, they could not manage their classroom activities effectively. For example, a student stated that: "Some teachers deliver lectures according to their students' mood and interest. Sometimes students don't want to learn anything, so teachers take the class in a flexible or light mood and could not manage their time effectively due to students' moods" (Student II).

Most students perceived that their teachers made schedules to run classroom activities smoothly and also shared their schedules with the students. Schedules of quizzes, assignments, and presentations were also shared with the students. For example, a student stated:

At the starting of the coursework, teachers establish their routines. The schedule of assignments and quizzes is determined. Teachers ask the students to select the topics according to students' interests for presentations. Teachers also share about deadlines of all these projects (Student VI). 
However, few students stated that some teachers with no proper routines could not even cover their syllabus, and the teachers who often remained on leave could not establish their routine to run classroom activities smoothly. Furthermore, very few students stated that teachers with no routines could not run classroom activities effectively since they entered the class and spent all their time in having a chitchat with a few favourite students.

\section{Discussion}

This small-scale qualitative study is the first to systematically explore the instructional effectiveness of university teachers in History classrooms in the Pakistani context. As such, the data collected through semi-structured interviews with History research students provided a nuanced and detailed description of perceptions of the lived experience in History classrooms. The more unobtrusive and anonymous style of research provided in-depth data (Brinkmann \& Kvale, 2018; Roulston \& Choi, 2018; Seidman, 2019), illuminating university teachers' instructional effectiveness through students' perceptions.

The first question that guided this study was related to students' perceptions of the effectiveness of students' engagement related practices of university teachers. Most students perceived that teachers motivated the students who show low interest in class by using different techniques like question answer, discussion, dealing the students with affection, giving examples of bright students. Moreover, very few teachers tried to find out the background reasons for students' low interest. Most students believed that their teachers engaged students to participate in co-curricular activities, whereas few students stated that their teachers avoided this. Most students perceived that teachers use different strategies to engage students in classroom activities by encouraging, motivating, questioning, providing them opportunities, and delivering lectures according to their mental level.

The second question that guided this study was related to students' perceptions of the effectiveness of classroom management related practices of university teachers. Teachers used a variety of instructional strategies such as lecture, discussion method, group work, and assigning the topics for presentations. Most students expressed that their teachers responded to the difficult questions of the students, while few students responded that teachers discouraged students' questioning and showed strict behaviour. Furthermore, most students stated that if teachers had no answer on the spot, then teachers would answer the question in the next class, and they perceived that their teachers considered individual differences of the 
students during the teaching-learning process, whereas some students responded that teachers had no such considerations. Findings revealed that teachers used different strategies for effective communication with the class: Most students perceived that teachers arranged the seats properly and also tried to make eye-to eye-contact with all students of the class, while few students stated that teachers used the questioning technique. Students perceived that their teachers used diverse strategies like assignments, presentations, articles, and book reviews to make them creative and to enhance their knowledge and skills. In addition, most students stated that their teachers used different strategies to remove hurdles in the teachinglearning process, while very few students had no good experience in this regard because teachers did not behave positively to remove their difficulties in learning.

The third question that guided this study was related to students' perceptions of the effectiveness of instructional strategies related to the practices of university teachers. The analysis revealed that students perceived that their teachers used diverse strategies such as questioning, motivating, and the threat of negative marking to ensure students' participation in classroom discussions. We found a diversity of perceptions about dealing with the disruptive behaviours of the students in the class. Most students perceived that teachers harshly or simply ignored such students; however, few students stated that teachers asked such students to repeat the lesson presented. Furthermore, very few students perceived that it depended upon teachers' mood; teachers could not punish at this level, so they insulted the disruptive students. When students' perceptions regarding time management were analyzed, it was concluded that the majority of the students were of the view that teachers managed their time to perform classroom activities effectively. Teachers use different techniques, like creating a friendly environment, caring for students' self-respect in good manners. Moreover, some students perceived that teachers behaved harshly to deal with the mischief of the disruptive students. Furthermore, findings of students' perceptions revealed diverse opinions about establishing routines by the teachers.

This diversity of students' perceptions of teachers' instructional practices clearly indicates that teachers need to amend practices in relation to student engagement, instructional strategies, and classroom management. Though most of the students identified their teachers' practices which are categorised as good practices in international literature 
on instructional strategies in history classrooms, some students preceptions highlight the problems in practice, which need to be addressed.

\section{Conclusion}

This study's results have highlighted the need for an important aspect of higher education, that is, effective teaching, in developing worldclass teaching and research culture in the classroom. University administration must recognize the importance of pedagogically trained teachers who are well versed in understanding the complexities of the teaching profession in the higher education context. There is a need to develop mechanisms for the professional development of faculty members in. In addition, there is a need to find ways to motivate history teachers to bring effectiveness to their instruction in the higher education classroom in order to develop effective hisotry teaching.

\section{Recommendations}

This study is limited by its reliance on a relatively small sample of students slected from a History Department of a public university. However, the findings of the current study have a number of implications for teaching in History classrooms in Pakistan.

It is recommended that teachers should consider individual differences of the students and understand their problems because students have individual differences and family problems that are responsible for students' hesitation and lack of proper attention towards their studies.

Moreover, teachers should use such techniques that are helpful in engaging students in co-curricular activities. Teachers should ensure students' participation in co-curricular activities for building their confidence.

In addition, it is recommended that teachers should review their instructional strategies to make their teaching effective because discouraging students' questioning badly affects students' learning and students become passive learners. Teachers should do their best to solve students' problems and difficulties in learning. Teachers' behaviour with students should not be influenced by the environment. On the bases of this finding that most teachers did not plan their activities, it is recommended that teachers should also review their routines and make proper planning for classroom teaching and the research work as well.

The findings of the current study raise several broad issues for future research: It is suggested that the same study may be conducted through a quantitative research design because using a large sample may result in the study generalizable to a large population. In addition, this 
study may be replicated in some other History classrooms in different geographical regions in Pakistan in order to develop more robust findings. This study was focused on a few dimensions of the instructional effectiveness of university teachers, aiming to keep the study manageable. This study gathered data from students enrolled in an MPhil History program. There is a need for a study that uses data from teachers and explores how teachers themselves judge their expertise in relation to various dimensions of instructional effectiveness.

\section{References}

Ahmad, I. (2004). Islam, democracy and citizenship education: An examination of the social studies curriculum in Pakistan. Current issues in comparative education, 7(1), 39-49.

Ahmad, I., Zeb, A., Rehman, S., Ahmad, S., Khan, W., Ahmad, K., \& Ghani, A. (2012). An evaluation of the effectiveness of teacher preparation programmes in khyber pakhtunkhwa province, pakistan. International Journal of Business and Social Research, 2(7), 124-131.

Andrade, A. D. (2009). Interpretive research aiming at theory building: Adopting and adapting the case study design. The Qualitative Report, 14(1), 42-60.

Aziz, K. K. (1998). The murder of history: A critique of history textbooks used in Pakistan. Delhi: Renaissance Publishing House.

Barton, K. C., \& Levstik, L. S. (2013). Teaching history for the common good. Mahwah, New Jersey: Lawrence Erlbaum Associates, Inc., Publishers.

Battistich, V., Schaps, E., \& Wilson, N. (2004). Effects of an elementary school intervention on students'“connectedness" to school and social adjustment during middle school. Journal of primary prevention, 24(3), 243-262.

Birch, S. H., \& Ladd, G. W. (1997). The teacher-child relationship and children's early school adjustment. Journal of school psychology, 35(1), 61-79. 
Bluestein, J. (2014). Managing 21st century classrooms: How do I avoid ineffective classroom management practices? Alexandria, VA: ASCD.

Brinkmann, S. (2013). Qualitative interviewing. Oxford: Oxford University Press.

Brinkmann, S., \& Kvale, S. (2018). Doing interviews ( $2^{\text {nd }}$ ed.). London: Sage.

Burden, R. L., \& Williams, M. (1997). Psychology for language teachers: a social constructivist approach. Cambridge: Cambridge University.

Charles, T., Kimutai, C. K., \& Zachariah, K. (2012). The Impact of Head Teachers' Supervision of Teachers on Students' Academic Performance. Journal of Emerging Trends in Educational Research and Policy Studies, 3(3), 299.

Dean, B. (2005). Citizenship education in Pakistani schools: Problems and possibilities. International Journal of Citizenship and Teacher Education, 1(2), 35-55.

Emmer, E. T., \& Stough, L. M. (2001). Classroom management: A critical part of educational psychology, with implications for teacher education. Educational Psychologist, 36(2), 103-112.

Evertson, C. M., \& Weinstein, C. S. (2011). Handbook of classroom management: Research, practice, and contemporary issues. New York: Routledge.

Fredricks, J. A., Blumenfeld, P. C., \& Paris, A. H. (2004). School engagement: Potential of the concept, state of the evidence. Review of Educational Research, 74(1), 59-109.

Garrett, T. (2014). Effective classroom management: The essentials. New York: Teachers College Press. 
Graham, P. (2007). Improving teacher effectiveness through structured collaboration: A case study of a professional learning community. RMLE Online, 31(1), 1-17.

HEC. (2016). Minimum criteria for admission in MS/Mphil/equivalent and Phd programs. Retrieved from https://www.hec.gov.pk/english/services/faculty/Plagiarism/Docum ents/Admission\%20Criteria\%202016.pdf

HEC. (2017). Curriculum Of History Bs \& Ms (Revised 2017). Retrieved from

https://hec.gov.pk/english/services/universities/RevisedCurricula/D ocuments/2016-2017/HISTORY.pdf

Jennings, P. A., \& Greenberg, M. T. (2009). The prosocial classroom: Teacher social and emotional competence in relation to student and classroom outcomes. Review of Educational Research, 79(1), 491525 .

Kaplan, D. S., Peck, B. M., \& Kaplan, H. B. (1997). Decomposing the academic failure-dropout relationship: A longitudinal analysis. The Journal of Educational Research, 90(6), 331-343.

Klem, A. M., \& Connell, J. P. (2004). Relationships matter: Linking teacher support to student engagement and achievement. Journal of school health, 74(7), 262-273.

Lall, M. (2008). Educate to hate: The use of education in the creation of antagonistic national identities in India and Pakistan. Compare, $38(1), 103-119$.

Laslett, R., \& Smith, C. (2002). Effective classroom management: A teacher's guide $\left(2^{\text {nd }}\right.$ ed.). London: Routledge.

Lewis, R. (2001). Classroom discipline and student responsibility: The students' view. Teaching and Teacher Education, 17(3), 307-319.

Lewis, R., Romi, S., Katz, Y. J., \& Qui, X. (2008). Students' reaction to classroom discipline in Australia, Israel, and China. Teaching and Teacher Education, 24(3), 715-724. 
Lune, H., \& Berg, B. L. (2017). Qualitative research methods for the social sciences. Essex: Pearson Education Limited.

MacSuga-Gage, A. S., Simonsen, B., \& Briere, D. E. (2012). Effective Teaching Practices: Effective Teaching Practices that Promote a Positive Classroom Environment. Beyond Behavior, 22(1), 14-22.

Merriam, S. B. (2009). Qualitative Research: A guide to design and implementation. San Francisco: John Wiley \& Sons.

Miles, M., Huberman, M., \& Saldaña, J. (2020). Qualitative data analysis: A methods sourcebook (4th ed.). New York: Sage Publications.

Nadeem, M., Rana, M. S., Lone, A. H., Maqbool, S., Naz, K., \& Akhtar, A. (2011). Teacher's competencies and factors affecting the performance of female teachers in Bahawalpur (Southern Punjab) Pakistan. International Journal of Business and Social Science, 2(19), 217-222.

Nayyar, A. H., \& Salim, A. (2003). The subtle subversion: The state of curricula and textbooks in Pakistan Urdu, English, Social Studies and Civics. Islamabad: Sustainable Development Policy Institute.

Orlich, D., Harder, R., Callahan, R., Trevisan, M., \& Brown, A. (2010). Teaching strategies: A guide to effective instruction $\left(9^{\text {th }}\right.$ ed.). Boston: Wadsworth, Cengage Learning.

Patton, M. Q. (2015). Qualitative research \& research methods $\left(4^{\text {th }}\right.$ ed.). Thousand Oaks: Sage Publications, Inc.

Peterson, P. E. (2011). Eighth-grade students learn more through direct instruction. Education Next, 11(3).

Rehmani, A. (2006). Teacher education in Pakistan with particular reference to teachers' conceptions of teaching. Quality in education: Teaching and leadership in challenging times, 20,, 495524

Reyes, M. R., Brackett, M. A., Rivers, S. E., White, M., \& Salovey, P. (2012). Classroom emotional climate, student engagement, and 
International Journal of Innovation in Teaching and Learning (IJITL)

Volume VII- Issue I (June 2021)

academic achievement. Journal of educational psychology, 104(3), 700-712.

Rogers, B. (2015). Classroom behaviour: A practical guide to effective teaching, behaviour management and colleague support. London: Sage.

Rosser, Y. (2003a). Curriculum as destiny: Forging national identity in India, Pakistan, and Bangladesh. (Unpublished doctoral dissertation), University of Texas, Austin. Retrieved from https://www.lib.utexas.edu/etd/d/2003/rosseryc036/rosseryc036.pd $\underline{\mathrm{f}}$

Rosser, Y. (2003b). Islamisation of Pakistani social studies textbooks. New Delhi: Rupa \& Co. in association with Observer Research Foundation.

Roulston, K. (2014). Analysing Interviews. In U. Flick (Ed.), The SAGE handbook of qualitative data analysis (pp. 297-312). London: Sage Publications Ltd.

Roulston, K., \& Choi, M. (2018). Qualitative interviews. In U. Flick (Ed.), The SAGE handbook of qualitative data collection (pp. 233-249). London: Sage Publications.

Saeed, M., \& Mahmood, K. (2002). Assessing competency of Pakistani primary school teachers in mathematics, science and pedagogy. International journal of educational management, 16(4), 190-195.

Saigol, R. (1995). Knowledge and identity: Articulation of gender in educational discourse in Pakistan. Lahore: ASR Publications.

Saldaña, J. (2011). Fundamentals of qualitative research. Oxford: Oxford University Press.

Saldaña, J. (2013). The coding manual for qualitative researchers $\left(2^{\text {nd }}\right.$ ed.). London: Sage Publications Ltd.

Saleem, A., Masrur, R., \& Afzal, M. T. (2014). Effect of Professional Development on Enhancing the Knowledge Level of University 
Teachers in Pakistan. Journal of Research \& Reflections in Education (JRRE), 8(2), $162-168$.

Saleem, A., Muhammad, Y., \& Masood, S. (2019). Negative emotions and self-created challenges of novice public-school teachers in managing classroom behaviour. Journal of elementary education, 29(2), 178-195.

Saleem, A., Muhammad, Y., \& Masood, S. (2020a). Classroom management challenges and administrative support in elementary schools: Experiences of novice public-school teachers. UMT Education Review, 3(2). Retrieved from https://journals.umt.edu.pk/index.php/uer/article/view/1100.

Saleem, A., Muhammad, Y., \& Masood, S. (2020b). Support needs of novice public-school teachers for effective management of elementary level classrooms in Lahore. Pakistan Social Sciences Review, 4, 682-697.

Schreier, M. (2014). Qualitative content analysis In U. Flick (Ed.), The SAGE handbook of qualitative data analysis (pp. 170-183). London: Sage Publications Ltd.

Scrivener, J. (2012). Classroom management techniques. New York: Cambridge University Press.

Seidman, I. (2006). Interviewing as qualitative research: A guide for researchers in education and the social sciences (3rd ed.). New York: Teachers College Press.

Seidman, I. (2019). Interviewing as qualitative research: A guide for researchers in education and the social sciences ( $5^{\text {th }}$ ed.). New York: Teachers College Press.

Shindler, J. (2009). Transformative classroom management: Positive strategies to engage all students and promote a psychology of success. New York: John Wiley \& Sons.

Skinner, E. A., \& Belmont, M. J. (1993). Motivation in the classroom: Reciprocal effects of teacher behavior and student engagement 
across the school year. Journal of educational psychology, 85(4), 571.

Stake, R. E. (1995). The art of case study research. London: Sage Publications Ltd.

Stake, R. E. (2013). Multiple case study analysis. New York: Guilford Press.

Urdan, T., \& Schoenfelder, E. (2006). Classroom effects on student motivation: Goal structures, social relationships, and competence beliefs. Journal of school psychology, 44(5), 331-349.

Westwood, P. (2009). What teachers need to know about students with disabilities. Victoria: ACER Press.

Yin, R. K. (2014). Case study research: Design and methods ( $5^{\text {th }}$ ed.). New York: Sage publications.

Yin, R. K. (2018). Case study research and applications: Design and methods $\left(6^{\text {th }}\right.$ ed.). New York: Sage publications.

Zaidi, S. M. A. (2011). Polarisation of social studies textbooks in Pakistan. The Curriculum Journal, 22(1), 43-59.

\section{Citation of this Article:}

Zaka, S., \& Muhammad, Y. (2021). Instructional Effectiveness in History Classrooms: An Analysis of Students' Perceptions of Instructional Practices of University Teachers. International Journal of Innovation in Teaching and Learning (IJTTL), 7(1), 39-62. 